\title{
A survey of storm-induced seaward-transport features observed during the 2019 and 2020 hurricane seasons
}

Jin-Si R. Over*1, Jenna A. Brown ${ }^{2}$, Christopher R. Sherwood ${ }^{1}$, Christie Hegermiller ${ }^{1}$, Phillipe A. Wernette $^{3}$, Andrew C. Ritchie ${ }^{3}$, Jonathan A. Warrick ${ }^{3}$

*Corresponding author: jover@usgs.gov

${ }^{1}$ U.S. Geological Survey, Coastal and Marine Science Center, Woods Hole, Massachusetts.

${ }^{2}$ U.S Geological Survey, Maryland-Delaware-D.C. Water Science Center, Dover, Delaware.

${ }^{3}$ U.S. Geological Survey, Pacific Coastal and Marine Science Center, Santa Cruz, California.

DISCLAIMER: This manuscript is a postprint published in Shore \& Beach on April 16th, 2021 in the Spring Special Issue: http://doi.org/10.34237/1008924 and is being hosted in the server EarthArXiv. Although the contents of this postprint are true and complete according to the authors and has been peerreviewed; future versions may have slightly different wording or figures as per the journal editors. Please contact the lead author Jin-Si Over (jover@usgs.gov) if you have any questions or comments about this manuscript. 


\begin{abstract}
Hurricanes are known to play a critical role in reshaping coastlines, particularly on the open ocean coast in cases of overwash, but storm induced seaward-directed flow and responses are often ignored or un-documented. Subaerial evidence for seaward sediment transport (outwash, return-flow) increases our understanding of the impact hurricanes have on coastal and barrier island evolution. Towards this goal we catalog all available National Geodetic Survey Emergency Response Imagery (ERI), the National Oceanic and Atmospheric Administration's (NOAA) collection of post-hurricane aerial imagery on the U.S East Atlantic and Gulf of Mexico coasts, for visible washout and return flow features. The most recent examples are from the North Core Banks, North Carolina, after Hurricane Dorian (2019), the Carolina coasts after Hurricane Isaias (2020), the Isles Dernieres, Louisiana, after Hurricane Zeta (2020), and the southwest coast of Louisiana, after Hurricanes Laura and Delta (2020); these include erosive scours and channels but also depositional deltas and fans on the shoreface and nearshore. Over the nearly $200 \mathrm{~km}$ of coastline analyzed, hundreds of seaward-flow features were identified; the density exceeds 20 per $\mathrm{km}$ in some areas. Individual features measure between $5 \mathrm{~m}$ and $500 \mathrm{~m}$ in both the along- and cross-shore dimensions. The extensive occurrence of these storm-induced return-flow and outwash morphologic features demonstrates that their sediment transport role may be more influential than previously thought. Based on these observations, we advocate for their inclusion in coastal change hazards classification schemes and coastal evolution morphodynamic models and propose an adoption of direction-explicit terms to use when describing return- and seaward-flow features to reduce redundant jargon and distinguish them from more frequently documented landward-flow features.
\end{abstract}

Keywords: barrier islands, return flow, seaward flow, morphology, hurricanes, NOAA, erosion, coastal evolution, aerial imagery, Gulf Coast, East Coast, storm processes, outwash, overwash

\title{
Introduction
}

Storm-Induced Flows

Hurricanes are known drivers of coastal geomorphic change (Hayes, 1967), and their impacts on

barrier islands and dune-beach systems have been well documented. Sallenger (2000) introduced a storm impact scale and argued that the greatest subaerial volumetric changes occurred in the overwash and inundation regimes. Under these regimes, onshore (landward-directed) flow overcomes the dune elevation and is a major factor in beach and barrier island evolution (e.g. Donnelly et al. 2006). An additional regime, “ebb-surge”, has been suggested to accommodate offshore or seaward-directed transport (e.g. Goff et al. 2010; Harter and Figlus 2017; Van der Lugt et al. 2019), although seaward transport can occur in each regime of the Sallenger scale. Seaward-flow features can form in a swash or collision regime: the formation of small-scale dendritic drainage features after receding surge are quite common and occur under normal ebb 
tide conditions or from rain-induced runoff (e.g. Pacheco 1992; Otvos 1999). In an overwash regime, low-elevation gaps in the dune crest can concentrate flow of elevated ocean waters and sediment to spread laterally on the back side of the dune; these gaps can also be exploited by elevated water levels on the landward side of the dunes resulting in overwash-like lobes on the beach face and nearshore. Inlets and outlets, either existing or created during a storm, can also act as direct conduits for sediment to be transported inland or offshore.

Flow direction is ultimately controlled by gradients in the water surface, which under storm conditions can be caused by winds, waves, tides, or runoff (e.g. Morton 2002; Engelstad et al. 2017). Landward flow is caused by elevated water levels on the ocean side of the coastline, typically driven by tides, storm surge, and wave setup and runup. Seaward flow occurs when water levels of inland water bodies (e.g. bays, estuaries, lagoons) or flooded land (or marsh) are higher than ocean levels as a result or combination of wind-driven setup in inland water bodies or runoff from upland precipitation. Return flow occurs when initial landward or seaward flow is followed by flow in the opposite direction, such as the flow that occurs as surge subsides. The path of the storm relative to the coastline (e.g. shore-normal or shore-parallel) is a large component of the forces responsible for driving storm-induced flows, where the direction and magnitude of the flow and resulting features depend on the location relative to the eye of the hurricane (Figure 1; e.g. Leatherman 1982, Penland and Suter 1984, Coch and Wolff 1991; Morton 2002). Additionally, wind and surge directions can reverse as the storm passes, a common occurrence (e.g. Wright et al. 1970) that can potentially affect either side of a barrier island (Figure 1). Water-level gradients can also be affected by timing lags associated with flow through inlets or other constrictions. 
Return- and seaward-flow events have been documented after hurricanes since the 1960s (Table 1, Table 2). There is a consistency in the types of features being described from Texas to the Carolinas, but the terminology used in the literature is inconsistent and do not describe all observed storm-induced processes and associated features. Our review of the commonly used terms suggests a directional component to describe the process, i.e "seaward", "ebb", "return", "offshore", "backwash", though landward-flow processes such as overwash and washover are associated with a landward direction without explicitly being labeled as such. The term "ebb", in reference to movement away from land, carries tidal connotations as the opposite of flood; however, it has been used to describe non-tidally forced bi-directional flows with implications that ebb flow was once a flood or landward flow (e.g. Hayes 1967; Hall et al. 1990; Priddy 1990; Coch and Wolff 1991; Goff et al. 2010; Sherman et al. 2013; Harter and Figlus 2016). To avoid invoking tidal terms, we use "return" to imply bi-directional flow over the course of a single event rather than as part of a cycle. This adjective can be applied to either landward or seaward flow; seaward return flow implies the direction was originally landward and landward return flow implies the direction was originally seaward. The latter is less frequently observed, but can occur, for example, when an inlet is breached by seaward flow and subsequent elevated water levels on the ocean side result in landward return flow.

\section{Storm-Induced Flow Features}

The geomorphic features formed from all types of flow processes have a variety of names and are generally classified as either erosional or depositional; fans, deltas, sheetwash, and splays imply deposition, while scour, drainage, channel, cut, and breach are terms that evoke erosion. Certain types have been further broken down, Sherman et al. (2013), for example, identified five types of scour channels observed after Hurricane Ike. But because the focus in this paper is 
subaerial, submerged features associated with offshore transport processes (e.g. undertow, rip currents, or turbidity flows) are beyond the scope of this paper.

Geomorphic features produced by return flow or seaward flow can appear similar to features formed by landward flow. For example, the overwash process, which creates washover fans (Table 1), has strong associations and connotations with landward flow; if a fan is formed from seaward-flow is it still a washover fan? What if a fan-like deposit is formed from return flow? We propose the use of terms that invoke more consistent directionality to describe the process and features of seaward flow (Table 1). To mirror overwash we propose the term outwash for the process of shallow, fast-moving, seaward-directed flows, which compliments the use of washout (Morton and Paine 1985; Morton 2002) as the result of outwash, and includes features like washout fans, channels, deltas, etc (Table 1). The term "ebb-" will be replaced with "return-" to describe features that are clearly the result of bi-directional flow.

The lasting effect of all these features on the dune and beach system as net sediment sinks and sources is still unclear. Though it is assumed if formed at a higher storm impact scale the transport potential will be greater. A better understanding of return and seaward flows and the features they form will be important in quantifying storm-induced sediment transport and their impacts on coastal resiliency.

\section{Observations}

The 2020 Atlantic and Gulf of Mexico hurricane season was the most active in the historical record and, in combination with the 2019 season, repeatedly brought storms and change to the coasts of the Carolinas and northern Gulf of Mexico. The National Oceanic and Atmospheric Administration (NOAA) Remote Sensing Division responded to seven hurricanes in 2019 and 2020, collecting and hosting Emergency Response Imagery though the National Geodetic Survey 
(NOAA/NGS ERI https://storms.ngs.noaa.gov/) as soon after each hurricane as possible. Imagery was acquired at altitudes between 750-1500 m, resulting in ground sample distances between 15 and $30 \mathrm{~cm}$. The flight extent was different for each response and the imagery after Hurricanes Zeta, Delta, Sally, Laura, Isaias, Dorian, and Barry spans the Texas-Louisiana border to the North Carolina-Virginia border (Table 2).

We visually examined the images for evidence of storm-induced coastal change. Return- and seaward-flow features were identified in the NOAA ERI from the Gulf of Mexico after Zeta, Delta, and Laura; near the South Carolina-North Carolina border after Isaias; and along the Outer Banks after Dorian (Figure 2). We also reviewed all available historical NOAA ERI, a total of 33 collections spanning from Hurricane Isabel in 2003 to Hurricane Michael in 2018, with the goal of cataloging the "rapidness" of the response, types of geomorphic features present, and their locations (Table 2). For exploratory purposes, quantitative metrics of feature length (cross-shore) and width (along-shore) were achieved by using the NOAA Web Map Tile Service (WMTS) v. 1.0.0 in ArcPro and measuring the features.

\section{Results}

Hurricane Dorian

After causing devastation in the Bahamas as a Category 5 storm Hurricane Dorian moved north, parallel to the East coast, where in early September 2019, the storm briefly made landfall at the tip of Cape Hatteras, North Carolina before it continued along the Gulf Stream to Canada (Figure 2). The shore-parallel path generated onshore winds and high surge from Florida to North Carolina. The NOAA ERI was flown along the coast on the same day and up to one day after the storm passed. A variety of features are visible in the imagery, including washover fans, sheetwash, deltas on the edge of inlets, and scours. The most prominent seaward-flow features were on the North Core Banks (Figure 3) where outwash, driven by winds and seiching from the 
sound side, flowed through previously established topographic lows to cut across the island and form washout channels. These low spots include past washover fans, relict tidal inlets, and beach access locations. The latter are generally not left to natural recovery processes - rather human presence reinforces them as vulnerable areas; these are plainly visible in 2019 pre-Hurricane Dorian imagery near the Great Island Cabins on the North Core Banks (https://geodesy.noaa.gov/storm_archive/coastal/viewer/index.html). More than ninety washout scours and channels were visible after Hurricane Dorian along the 30-km long barrier island. At least three different types of features are present: channels that cut across the entire island, singular channels that cut across the dune, and nested dendritic channels and scours (Figure 3). The washout channels are similar in size and shape to those formed by Hurricane Harvey (2017) at Port Aransas, TX (Goff et al. 2019) and share morphological similarities to the long scour types on the Bolivar Peninsula (Sherman et al. 2013).

\section{Hurricane Isaias}

The ninth named storm and second hurricane of the 2020 season, Isaias made its way up the Florida coast in late July and early August as a tropical storm before it strengthened to a Category 1 offshore and parallel to the South Carolina coast. Isaias made landfall on the South Carolina-North Carolina border (Figure 2) and rapidly progressed north once more as a tropical storm. A high wrack line on the berm was the only impact on the Florida coast, whereas areas of overwash became more distinguishable in parts of South Carolina. Return-flow features were present on both sides of the North Carolina border, where the storm track ran offshore and parallel to the coastline (Figure 2; Figure 4). Many were similar to type 1 (small and geometric) and 5 (short channels) scours (Sherman et al. 2013; Figure 4B). Along the Myrtle Beach intertidal zone, similar drainage patterns were continuous, though they may be the result of the last high tide as imagery was not always taken the same day as the storm passed (Table 2). 


\section{Hurricanes Laura and Delta}

Hurricane Laura came ashore perpendicular to the Louisiana coast near the Texas border as a Category 4 in late August of 2020 (Figure 2). The greatest wind and storm surge (2.8 m maximum) occurred on the eastern side of the eye while disproportionality more rain $(\sim 15 \mathrm{~cm}$ more) fell on the western side (National Hurricane Center, 2020). In early October, Hurricane Delta made landfall just $20 \mathrm{~km}$ to the east of Laura as a Category 2. Some of the features created by Laura persisted and appear to have been slightly reworked or reactivated by Delta (Figure 5).

The affected coastline ranged from the Texas-Louisiana border to east of Cheniere au Tigre Parish, Louisiana, where the NOAA ERI ends. Inland of the coast, the terrain ranges from roads and forest to ponds, marsh, and irrigation or retention ditches. In some places, seaward of the beach, breakwaters and groins helped shape and alter the flow. To the west of where Laura and Delta made landfall, the seaward-flow features were predominantly formed by outwash (Figure 6A), similar to those on the North Core Banks and the Texas barrier islands from Hurricanes Dorian (Figure 3) and Harvey (Goff et al. 2019) and Alicia (Morton 2002), respectively. Particularly large (>50 m long and $>20 \mathrm{~m}$ wide) washout channels were located near Louisiana Highway 27, east of Holly Beach, where about twenty closely clustered channels dissected the beach over less than $2 \mathrm{~km}$ after Delta (Figure 6A). A series of ponds and an irrigation channel were separated from the beach only by a road, and these were likely a source of water that created the washout features. These erosional washout features, while varying in size and density, were the predominant features along the coastline for about $25 \mathrm{~km}$ to the west of the approximate landfall of Delta. To the east of the eye, the storm-induced seaward flow features looked distinctly different than features west of the eye because they had a depositional component in the nearshore (Figure 6B and 6C). These types of seaward return-flow features 
were discontinuous for about $90 \mathrm{~km}$ until the end of the ERI and formed stretches of anastomosing fans and individual deltas.

The location of the erosional and depositional features with respect to the eye of the storm were consistent with the general wind and surge directions of a shore-normal hurricane (Figure 1). The outwash features to the west of the eye were a result of uni-directional seaward flow whereas, on the east side of the eye, the beaches were affected by bi-directional flow: landward surge and return flow components forced by the hurricane path produced both overwash and seaward return features (Figure 6B and 6C). Similar return-flow features were reported to the east of Hurricane Ike's landfall in Figure 13 of Byrnes and McBride (2009), which had visibly elevated water levels landward of the coast that resulted in nearshore deltas.

\section{Hurricane Zeta}

In late October, Hurricane Zeta became the $5^{\text {th }}$ named storm in 2020 to make landfall in Louisiana. As a Category 2, Zeta brought high winds and surge farther east than Laura and Delta, and moved north, parallel and to the east of the Chandeleur Islands (Figure 2). To the west of the eye, conditions were conducive to seaward flow on the Isles Derniere Barrier Island Refuge, where washout fans formed (Figure 7A). As the hurricane moved north towards the Chandeleurs, winds and surge favored overwash and inundation into the sound; after the storm passed, flow switched directions. The seaward return flow was indicated by asymmetric ripples with the stoss or gradual sloping feature on the landward side and seaward-oriented drainage channels (Figure 7B).

\section{Discussion - Implications for Coastal Evolution}

Seaward return-flow features appear in the NOAA ERI more often ( $70 \%$ of storms) than seawardflow features ( $\sim 30 \%$ of storms). Conditions that result in seaward return-flow events are generally more common than those that generate uni-directional seaward-flow because most storms have 
initial flooding from offshore and some degree of inland runnoff. Flooding generated by initial landward flow establishes the potential for return flow during runoff as the surge relaxes, this can be exacerbated by existing water bodies or low elevations that more effectively pool water and increase the land to ocean water gradient. Seaward-flow feature frequency was similar among both Atlantic and Gulf of Mexico storm events, but return-flow features were 50\% more common in the Gulf (Table 2). The similar frequency of seaward flow features is somewhat surprising as, in terms of elevation, the barrier islands that line the U.S Atlantic coast are generally higher and wider than those in the Gulf of Mexico, the latter of which would take less energy to submerge from the inland side. A storm such as Dorian, which allowed outwash along North Core Banks, North Carolina in multiple places from the sound is still a rarer occurrence than conditions that favor overwash, previous events with similar washout features with NOAA ERI include Hurricanes Irene (2011; Figure 8) and Ophelia (2005; Table 2). Pre-ERI, Hurricane Emily (1993) was a shoreparallel hurricane passing close to Cape Hatteras that flooded the barrier island from the sound side stopping just short of outwash onto the beach; a wrack line on the backside of the dune indicated surge was just shy of complete inundation or breaching of the dune (Bush et al. 1996).

The ubiquity of return- and seaward-flow features in the NOAA ERI suggests they are likely formed more frequently than the literature suggests. Their relative lack of documentation pre-early 2000s may be contributed to return-flow deltas and washout channels higher chances of being reworked onto the beach or filled in and due to delays in capturing post-storm observations and imagery. This may have resulted in a reporting bias that favors overwash features, which tend to have a better preservation record. That said, not all the seaward-flow features observed were short lived, as the seaward return deltas formed by Hurricane Laura persisted for two months and were reworked and expanded by Hurricane Delta (Figure 5). The large washout channels formed after 
Dorian on North Core Banks are also still visible in the Isaias imagery almost a full year later, although they have partially filled with washover deposits. The persistence of these features indicates that seaward flow can affect beach morphology over time scales of at least a year.

The NOAA ERI dataset demonstrates that these features are more common than previously thought, but the role of return and seaward flow in coastal sediment budgets is still poorly understood. The volume of sediment transported offshore and, potentially, out of the system by these events is difficult to calculate, as timely pre- and post-storm elevational data covering the entire impacted zone (subaerial and subaqueous) are usually unavailable. Aerial imagery does not provide much information regarding the volume and fate of sediment in submerged nearshore regions, although structure-from-motion practices have the potential to create elevation models from the subaerial parts of coastal imagery (Over et al. [In Press]). Morton and Paine (1985) attempted to quantify the volume of sediment lost and returned to Galveston Island after Hurricane Alicia (1983) by extrapolating pre- and post-storm beach profiles and calculating the volume of washover deposits; they estimated $88 \%$ of the eroded sediment was carried offshore (not deposited by overwash) and two years later about $50 \%$ of that volume had returned to the beach. Bathymetric surveys and coring have also identified hurricane turbidite deposits off the Texas coast (e.g. Hayes 1967; Goff et al. 2010), and while quantitative measurements have been made of the change in depth of large channels (Goff et al. 2019), the post-storm fate of the sediment is largely left to numerical coastal processes models.

High-resolution, process-based morphodynamic models can be used to characterize the storminduced hydrodynamics which drive return and seaward flow, identify the critical factors that influence the formation of erosional and depositional features, and determine the fate of sediment transported during these events. Several modeling and observational efforts have analyzed 
seaward-directed flow during hurricanes and large storms but have largely focused on the hydrodynamic conditions. Sherwood et al. (2014) highlighted the importance of back-barrier dynamics in modeling morphologic change during large storms and presented several mechanisms that could lead to return or seaward flow. Engelstad et al. (2017) cited delicate balances between nearshore water level gradients and large-scale gradients, such as those that drive return or seaward flow, as critical in determining the magnitude of transport. Variations in bed roughness, e.g. from vegetation, also control the location of erosional features created by seaward flow (e.g. Passeri et al. 2018; van der Lugt et al. 2019). Infrastructure and geoengineering also has an impact, as seen most recently in Hurricane Isaias, Laura, and Delta (Figure 4A, Figure 6A and B), where houses, beach-access gaps in dunes, roads, groins, and breakwaters can alter flow and influence sediment transport; this remains a field of interest (e.g. Lennon 1991; Bush and Pilkey 1994; Morton 2002; Nederhoff et al. 2015). Ultimately, morphodynamic models are not yet widely applied to explore outwash or return-flow sediment transported offshore from the beach-dune system during and after storm events on immediate or long-term time scales.

The likelihood is that, in most cases, erosional return and washout features are not removing a large amount of sediment from the active system in Atlantic and Gulf coastal environments, though this assumption would benefit further study. Rather, sediment is being redistributed from dunes or inland regions to the beach face or nearshore, where it is deposited as washout fans or deltas and becomes available for transport alongshore or back onshore, to be incorporated into nearshore bars or as berms welded to the intertidal beach. Longer-lasting changes may result from formation of inland ponds if larger washout channels do not infill immediately. The destruction of dune systems and the creation of new inlets may be the most significant return- or 
seaward-flow processes for sediment transport, but these also can occur during landward flow. Overall, if sediment remains close to shore it will likely be returned to the beach system when energy conditions return to normal, as would appear likely in Hurricanes Isaias and the east side of Laura and Delta. In contrast, sediment transported far offshore after a storm (e.g. Hayes 1967; Gayes 1991; Goff et al. 2010) through inlets or large return channels may be lost from the beachdune system, as may have happened recently on North Core Banks during Hurricane Dorian and in Louisiana west of Hurricane Delta.

\section{Conclusions}

Storm-induced coastal hazards are typically characterized according to ocean-side processes, linking ocean water levels to ocean-side topography, such as the elevation of dune toe and crest on barrier islands in the original Sallenger (2000) storm impact scale. Through frameworks with this perspective, coastal hazard events with water levels that affect back-barrier topography and coasts beyond barrier islands are unresolved. The widespread identification of seaward- and return- flow features that result from these overlooked storm processes indicates a need to better understand and incorporate them in storm-impact studies and operational models. To start, differences in sediment transport and fate, driven by the complexity and dynamic nature of storms and the coastal landscape, need a clear set of terms with a directional component that distinguishes between all storm-induced features, which are defined here. As described, seaward return flow and outwash, the process associated with uni-directional seaward flow, occurs when (i) the inland water elevation (in a marsh, sound, lagoon, etc.) is significantly above the coastal landform, and (ii) a significant water-level gradient exists through a connection between the backwater and the ocean, thereby inducing flow. Once these conditions are met, the resulting flow dynamics and erosional and depositional patterns are a function of many things, including 
the relation to the storms path, duration and magnitude of elevated water levels and waves, volume and supply of backwater, infrastructure, and the characteristics of the coastal landform.

The increased availability of rapid-response aerial imagery immediately following hurricanes provides mounting evidence that storm-induced, seaward-return flow and the outwash process are both more common than previously reported. The very active 2019 and 2020 hurricane seasons resulted in hundreds or diverse return- and seaward-flow features, some of which will likely influence, for better or worse, the shape and use of the coast months to years after formation. Our documentation of these features throughout the NOAA ERI collection also highlights a gap in existing operational coastal hazard prediction models (Sallenger (2000); Stockdon et al. 2007; Leaman et al, 2020 Pre-print) that do not consider seaward-flow processes in the coastal landscape's response to hurricanes, an oversight that we advocate should be corrected.

\section{Acknowledgments}

This work has been supported by the U.S. Geological Survey Coastal/Marine Hazards and Resources Program and by Congressional appropriations through the Additional Supplemental Appropriations for Disaster Relief Act of 2019 (H.R. 2157). The authors thank Dr. Jen Miselis and two anonymous reviewers for comments that greatly improved this manuscript. We also thank the NOAA ERI team for technical discussions and data access.

Any use of trade, firm, or product names is for descriptive purposes only and does not imply endorsement by the U.S. Government.

\section{References}

Bush, D.M. and Pilkey, O.H., 1994. "Mitigation of hurricane property damage on barrier islands: a geological view.” Journal of Coastal Research, 311-326.

Bush, D.M., Young, R.S., Webb, C.A. and E.R. Thieler, 1996. "Soundside impacts of a northward tracking tropical cyclone: Hurricane Emily (31Aug93), Cape Hatteras area, North Carolina.” Journal of Coastal Research, 229-239. 
Byrnes, M.R. and McBride R.A., 2009. "Coastal response to Hurricane Ike (2008): Southwest Louisiana and Southeast Texas." Shore and Beach, 77(2), 37-48.

Coch, N.K. and Wolff, M.P., 1991. "Effects of Hurricane Hugo storm surge in coastal South Carolina." Journal of Coastal Research, 201-226.

Donnelly, C., Kraus, N., and M. Larson, 2006. "State of knowledge on measurement and modeling of coastal overwash.” Journal of Coastal Research, 22(4), 965-991.

Engelstad, A., Ruessink, B.G., Wesselman, D., Hoekstra, P., Oost, A., and M. van der Vegt, 2017. "Observations of waves and currents during barrier island inundation." Journal of Geophysical Research Oceans, 122(4), 3152-3169.

Gayes, P.T., 1991. "Post-Hurricane Hugo nearshore side scan sonar survey; Myrtle Beach to Folly Beach, South Carolina.” Journal of Coastal Research, 95-111.

Goff, J.A., Allison, M.A., and S.P. Gulick, 2010. "Offshore transport of sediment during cyclonic storms: Hurricane Ike (2008), Texas Gulf Coast, USA.” Geology, 38(4), 351354.

Goff, J.A., Swartz, J.M., Gulick, S.P., Dawson, C.N., and A.R. de Alegria-Arzaburu, 2019. “An outflow event on the left side of Hurricane Harvey: Erosion of barrier sand and seaward transport through Aransas Pass, Texas." Geomorphology, 334, 44-57.

Guidroz, W.S., Stone, G.W. and D. Dartez, 2007. "Sediment transport along the Southwestern Louisiana shoreline: impact from Hurricane Rita, 2005.” Coastal Sediments', 911-920.

Hall, M.J., Young, R.S., Thieler, E.R., Priddy, R.D., and O.H. Pilkey Jr., 1990. "Shoreline response to hurricane Hugo.” Journal of Coastal Research, 211-221.

Harter, C. and Figlus, J., 2017. "Numerical modeling of the morphodynamic response of a lowlying barrier island beach and foredune system inundated during Hurricane Ike using XBeach and CSHORE." Coastal Engineering, 120, 64-74.

Hayes, M.O. 1967. "Hurricanes as Geological Agents: Case Studies of Hurricanes Carla, 1961, and Cindy, 1963." Report of Investigations 61. Austin, TX: Bureau of Economic Geology, University of Texas.

Kahn, J.H., 1986. "Geomorphic recovery of the Chandeleur Islands, Louisiana, after a major hurricane.” Journal of Coastal Research, 337-344.

Leaman, C.K., Harley, M.D., Splinter, K.D., Thran, M.C., Kinsela, M.A. and I.L. Turner, 2020. "A Storm Hazard Matrix combining coastal flooding and beach erosion." Pre-print at https://doi.org/10.31223/X5Q592

Leatherman, S.P., 1982. Barrier island handbook, Coastal Publications.

Lennon, G., 1991. "The nature and causes of hurricane-induced ebb scour channels on a developed shoreline.” Journal of Coastal Research, 237-248. 
Morton, R.A. and Paine, J.G., 1985. "Beach and vegetation-line changes at Galveston Island, Texas: erosion, deposition, and recovery from Hurricane Alicia." Geological Circular, $85(5)$.

Morton, R.A., 2002. "Factors controlling storm impacts on coastal barriers and beaches: a preliminary basis for near real-time forecasting." Journal of Coastal Research, 486-501.

National Geodetic Survey (NGS), 2020a. "NOAA NGS Emergency Response Imagery: Hurricane Zeta." NOAA National Centers for Environmental Information, https://www.fisheries.noaa.gov/inport/item/63139.

NGS, 2020b. "NOAA NGS Emergency Response Imagery: Hurricane Delta.” NOAA National Centers for Environmental Information, https://www.fisheries.noaa.gov/inport/item/63057.

NGS, 2020c. "NOAA NGS Emergency Response Imagery: Hurricane Laura.” NOAA National Centers for Environmental Information, https://www.fisheries.noaa.gov/inport/item/62819.

NGS, 2020d. "NOAA NGS Emergency Response Imagery: Hurricane Isaias.” NOAA National Centers for Environmental Information, https://www.fisheries.noaa.gov/inport/item/62679.

NGS, 2019a. "NOAA NGS Emergency Response Imagery: Hurricane Dorian.” NOAA National Centers for Environmental Information, https://www.fisheries.noaa.gov/inport/item/57856.

NGS, 2019b. "NOAA NGS Emergency Response Imagery: Hurricane Barry." NOAA National Centers for Environmental Information, https://www.fisheries.noaa.gov/inport/item/57817.

NGS, 2018. "NOAA NGS Emergency Response Imagery: Hurricane Florence.” NOAA National Centers for Environmental Information, https://www.fisheries.noaa.gov/inport/item/57677.

NGS, 2011. "Hurricane Irene: Rapid Response Imagery of the Surrounding Regions". NOAA National Centers for Environmental Information, http://ngs.woc.noaa.gov/storms/irene/. Otvos, E.G., 1999. "Rain-induced beach processes; landforms of ground water sapping and surface runoff." Journal of Coastal Research, 1040-1054.

National Hurricane Center, 2020. "Hurricane LAURA". https://www.nhc.noaa.gov/archive/2020/al13/. Accessed January 28, 2021.

Nederhoff, C.M., Lodder, Q.J., Boers, M., Den Bieman, J.P. and J.K. Miller, 2015. "Modeling the effects of hard structures on dune erosion and overwash: A case study of the impact of Hurricane Sandy on the New Jersey coast." The Proceedings of the Coastal Sediments, https://doi.org/10.1142/9789814689977_0219. 
Otvos, E.G., 1999. "Rain-induced beach processes; landforms of ground water sapping and surface runoff." Journal of Coastal Research, 1040-1054.

Over, J.R., Ritchie, A.C., Kranenburg, C., Brown, J.A., Buscombe, D.D., Noble, T., Sherwood, C.R., Warrick, J., and Wernette, P.A., [in press], "Processing coastal imagery with Agisoft Metashape Professional Edition, version 1.6- Structure from motion workflow documentation.” U.S. Geological Survey, Open-File Report 2021-1039. https://doi.org/10.3133/ofr20211039

Pacheco J.M., 1992. "A simple modeling of braid-like structures (rill marks) appearing on sandy beaches."

Passeri, D.L., Long, J.W., Plant, N.G., Bilskie, M.V. and S.C. Hagen, 2018. "The influence of bed friction variability due to land cover on storm-driven barrier island morphodynamics." Coastal Engineering, 132, 82-94.

Penland, S. and Suter, J.R., 1984. "Low-profile barrier island overwash and breaching in the Gulf of Mexico.” Coastal Engineering Proceedings, 19, 157-157.

Sherman, D. J., Hales, B.U., Potts, M.K., Ellis, J.T., Hongxing, L., and C. Houser, 2013. "Impacts of Hurricane Ike on the beaches of the Bolivar Peninsula, TX, USA." Geomorphology, 199, 62-81.

Sherwood, C.R., Long, J.W., Dickhudt, P.J., Dalyander, P.S., Thompson, D.M. and N.G. Plant, 2014. "Inundation of a barrier island (Chandeleur Islands, Louisiana, USA) during a hurricane: Observed water-level gradients and modeled seaward sand transport." Journal of Geophysical Research: Earth Surface, 119, 1498-1515.

Stockdon, H.F., Sallenger Jr, A.H., Holman, R.A. and Howd, P.A., 2007. “A simple model for the spatially-variable coastal response to hurricanes.” Marine Geology, 238, 1-20.

van der Lugt, M.A., Quataert, E., van Dongeren, A., van Ormondt, M. and C.R. Sherwood, 2019. "Morphodynamic modeling of the response of two barrier islands to Atlantic hurricane forcing." Estuarine, Coastal and Shelf Science, 229, 106404.

Wright, L.D., Swaye, F.J., and J.M Coleman, 1970. "Effects of Hurricane Camille on the landscape of the Breton-Chandeleur Island chain and the eastern portion of the Lower Mississippi Delta.”, Coastal Studies Bulletin, 76(4), 1-25. 


\section{Tables}

Table 1. Classification scheme for the storm processes and features described in this paper based on the direction of flow. Brackets "[ ]" indicate terms used in the literature with similar process implications

\begin{tabular}{|c|c|c|c|}
\hline & $\begin{array}{l}\text { Landward flow } \\
\text { (unidirectional flow) }\end{array}$ & $\begin{array}{c}\text { Return flow }^{1} \\
\text { (bi-directional flow) }\end{array}$ & $\begin{array}{l}\text { Seaward flow } \\
\text { (unidirectional flow) }\end{array}$ \\
\hline Process & $\begin{array}{l}\text { overwash, flood } \\
\text { surge }\end{array}$ & $\begin{array}{l}\text { seaward or landward } \\
\text { return flow } \\
\text { [storm-surge ebb², ebb- } \\
\left.\text { flow }^{2}, \text { backwash }^{3}\right]\end{array}$ & $\begin{array}{c}\text { outwash }^{*} \\
\text { [reverse-flow }{ }^{4} \text { outflow }{ }^{5} \\
\left.\text { seaward directed surge }{ }^{5}\right]\end{array}$ \\
\hline $\begin{array}{l}\text { Feature } \\
\text { Depositional }\end{array}$ & $\begin{array}{l}\text { washover fan, } \\
\text { sheetwash } \\
\text { (Figure 3A) }\end{array}$ & $\begin{array}{l}\text { return [ebb] fan, delta } \\
\text { (Figure } 4 C, 5,6 B, 6 C \text { ) }\end{array}$ & $\begin{array}{c}\text { washout }^{6} \text { fan (Figure } 7 \mathrm{~A} \text { ) } \\
\text { splay (Figure } 8 \text { ) }\end{array}$ \\
\hline Erosional & $\begin{array}{c}\text { washover } \\
\text { channel, breach }^{\star *}\end{array}$ & $\begin{array}{c}\text { return [ebb] scour } \\
\left.\text { channel }^{7} \text { (Figure } 4 \mathrm{~A}, 4 \mathrm{~B}\right) \\
\text { [ebb] surge channel }^{8}\end{array}$ & $\begin{array}{c}\text { washout scour, channel, } \\
\text { breach, cut } \\
\text { (Figure 3B, 6A, 8) }\end{array}$ \\
\hline
\end{tabular}

*New term proposed in this paper

*thttps://storms.ngs.noaa.gov/storms/gordon/index.html\#17/30.24418/-88.22954

${ }^{1}$ Wright et al. 1970; Kahn 1986; Morton 2002; Guidroz et al. 2007

${ }^{2}$ Hayes 1967; Hall et al. 1990; Coch and Wolff 1991; Gayes 1991; Morton 2002; Goff et al. 2010;

Sherman et al. 2013; Harter and Figlus 2016

${ }^{3}$ Nederhoff et al. 2015

${ }^{4}$ Bush and Pilkey 1994

${ }^{5}$ Goff et al. 2019

6Morton and Paine 1985; Morton 2002

${ }^{7}$ Lennon 1991; Sherman et al. 2013

${ }^{8}$ Gayes 1991

Table 2 Catalog of NOAA Emergency Response Imagery return- and seaward- flow features (washover features may also be present). "Category" is based on the Saffir-Simpson scale of the storm when it passed over where the images were taken and "Days" represents how soon after the hurricane passed were images taken

\begin{tabular}{lcccccc}
\hline Hurricane & Year & Category & Days & $\begin{array}{c}\text { Seaward- } \\
\text { flow } \\
\text { features } \\
(\mathbf{Y} / \mathrm{N})\end{array}$ & $\begin{array}{c}\text { Return- } \\
\text { flow } \\
\text { features } \\
\text { (Y/N) }\end{array}$ & Location \\
\hline Zeta & 2020 & 2 & $1-2$ & $\mathrm{Y}$ & $\mathrm{Y}$ & $\begin{array}{c}\text { Isles Dernieres, } \\
\text { Chandeleurs, LA }\end{array}$ \\
\hline Delta & 2020 & $1-2$ & $0-1$ & $\mathrm{Y}$ & $\mathrm{Y}$ & $\begin{array}{c}\text { SW Louisiana, TX-LA } \\
\text { border }\end{array}$ \\
\hline Sally & 2020 & 2 & $2-5$ & $\mathrm{~N}$ & $\mathrm{~N}$ & Alabama
\end{tabular}




\begin{tabular}{|c|c|c|c|c|c|c|}
\hline Laura & 2020 & 4 & $0-4$ & $\mathrm{~N}$ & $\mathrm{Y}$ & SW LA, TX-LA border \\
\hline Isaias & 2020 & 1 & $1-2$ & $\mathrm{~N}$ & $\mathrm{Y}$ & $\begin{array}{c}\text { Friendfield, Pawleys Island } \\
\text { Beach, Ingram Beach, SC; } \\
\text { Long Beach, Oak Island, } \\
\text { NC }\end{array}$ \\
\hline Dorian & 2019 & 2 & $0-1$ & $\mathrm{Y}$ & $\mathrm{N}$ & Core Banks, NC \\
\hline Barry & 2019 & 1 & $3-6$ & $\mathrm{~N}$ & $\mathrm{~N}$ & Gulf Coast \\
\hline Michael & 2018 & 5 & $1-4$ & $\bar{N}$ & $\mathrm{Y}$ & $\begin{array}{l}\text { St. Andrews State Park, } \\
\text { Salinas Park, FL }\end{array}$ \\
\hline Florence & 2018 & $1-2$ & $1-8$ & $\mathrm{~N}$ & $\mathrm{~N}$ & Atlantic Coast \\
\hline Gordon & 2018 & TS & $1-2$ & $\mathrm{~N}$ & $\mathrm{Y}$ & $\begin{array}{c}\text { Waveland, Longbeach, } \\
\text { Mississippi City Pascagoula } \\
\text { Beach, MS; Dauphin Island, } \\
\text { AL }\end{array}$ \\
\hline Nate & 2017 & 1 & 2 & $\mathrm{~N}$ & $\mathrm{~N}$ & Gulf Coast \\
\hline Maria & 2017 & $2-4$ & $2-6$ & $\mathrm{~N}$ & $\mathrm{~N}$ & Puerto Rico \\
\hline Irma & 2017 & $3-4$ & $1-8$ & $\mathrm{~N}$ & $\mathrm{~N}$ & Florida \\
\hline Harvey & 2017 & TS-4 & $1-5$ & $\mathrm{Y}$ & $\mathrm{N}$ & $\begin{array}{l}\text { Mustang Island, Port } \\
\text { Aransas, TX }\end{array}$ \\
\hline Matthew & 2016 & $1-4$ & $0-6$ & $\mathrm{Y}$ & $\mathrm{Y}$ & $\begin{array}{l}\text { Starting at St. Andrew } \\
\text { Sound, GA, most of the SC } \\
\text { coast to the NC border }\end{array}$ \\
\hline Arthur & 2014 & 2 & 0 & $\mathrm{Y}$ & $\mathrm{Y}$ & $\begin{array}{c}\text { Cape Hatteras, New Inlet } \\
\text { Bridge, NC }\end{array}$ \\
\hline Sandy & 2012 & ET-1 & $1-7$ & $\mathrm{~N}$ & $\mathrm{Y}$ & Cape May, Sandy Hook, NJ \\
\hline Isaac & 2012 & 1 & $2-4$ & $\mathrm{~N}$ & $\mathrm{Y}$ & $\begin{array}{c}\text { North of Grand Isle, East } \\
\text { Timbalier Island, } \\
\text { Chandeleurs, Gulf Port, LA; } \\
\text { Fort Morgan to Gulf Shores, } \\
\text { AL }\end{array}$ \\
\hline Irene & 2011 & 1 & $1-3$ & $\mathrm{Y}$ & $\mathrm{Y}$ & $\begin{array}{l}\text { Rodanthe, New Inlet, Pea } \\
\text { Island, Oregon Inlet, NC }\end{array}$ \\
\hline Earl & 2010 & 2 & 0 & $\mathrm{~N}$ & $\mathrm{~N}$ & North Carolina \\
\hline Ike & 2008 & 2 & $1-4$ & $\mathrm{~N}$ & $Y$ & $\begin{array}{c}\text { Deep Lake, Cameron, } \\
\text { Grand Chenier coast, LA; } \\
\text { Bolivar Peninsula, Clam } \\
\text { Lake, TX }\end{array}$ \\
\hline Gustav & 2008 & 1 & $1-6$ & $\mathrm{~N}$ & $\mathrm{Y}$ & Dauphin Island, AL \\
\hline Humberto & 2007 & 1 & $2-3$ & $\mathrm{~N}$ & $\mathrm{Y}$ & Star Lake area, TX \\
\hline Ernesto & 2006 & TS & $1-3$ & $\mathrm{~N}$ & $\mathrm{~N}$ & North Carolina \\
\hline Wilma & 2005 & $2-3$ & $1-3$ & $\mathrm{~N}$ & $\mathrm{Y}$ & $\begin{array}{l}\text { Marcos Island, Cape } \\
\text { Ramano Island, FL }\end{array}$ \\
\hline Rita & 2005 & $1-3$ & $2-7$ & $\mathrm{~N}$ & $\mathrm{Y}$ & $\begin{array}{l}\text { Peveto Beach, Johnson } \\
\text { Bayou, TX; }\end{array}$ \\
\hline Ophelia & 2005 & 1 & 2 & $\mathrm{~N}$ & $\mathrm{Y}$ & $\begin{array}{l}\text { Cape Lookout National } \\
\text { Seashore, NC }\end{array}$ \\
\hline Katrina & 2005 & $3-5$ & $1-7$ & $\mathrm{~N}$ & $\mathrm{Y}$ & $\begin{array}{c}\text { LA coast and barrier } \\
\text { islands; Dauphin Island, MS } \\
\text { coast }\end{array}$ \\
\hline
\end{tabular}




\begin{tabular}{llllllc}
\hline Dennis & 2005 & 3 & $?$ & Y & Y & $\begin{array}{c}\text { Seminole Hills, Grayton } \\
\text { Beach, Point Washington, } \\
\text { FL }\end{array}$ \\
\hline Ivan & 2004 & 3 & $?$ & Y & Y & $\begin{array}{c}\text { Pine Beach, Gulf Shores, } \\
\text { AL; Gulf Breeze, Navarre, } \\
\text { FL }\end{array}$ \\
\hline Jeanne & 2004 & 3 & $?$ & N & N & Florida \\
\hline Isabel & 2003 & 2 & $?$ & N & Y & $\begin{array}{c}\text { Cape Lookout National } \\
\text { Seashore, Cape Hatteras } \\
\text { National Seashore, NC }\end{array}$
\end{tabular}

\section{Figures}


Shore-normal Hurricane
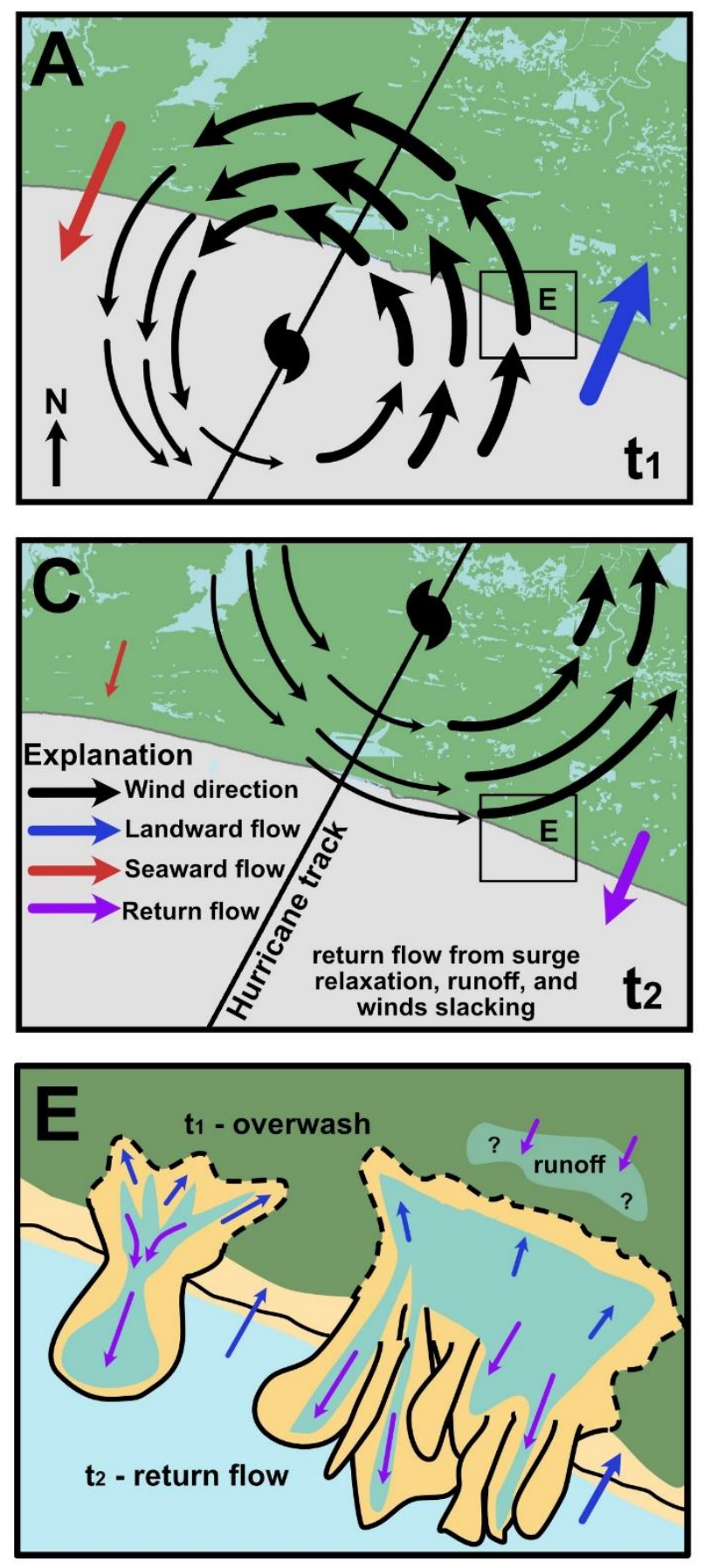

\section{Shore-parallel Hurricane}
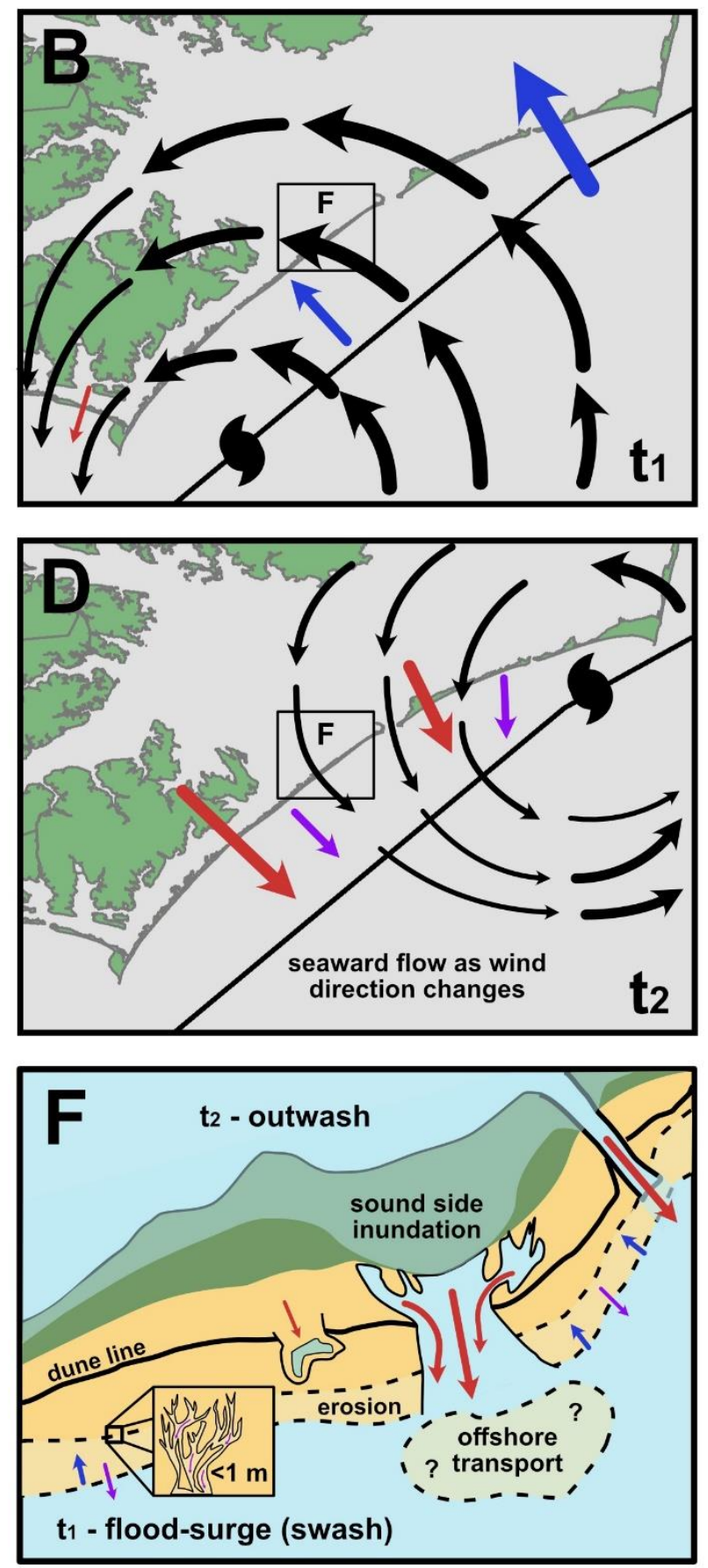

Figure 1. Map showing the general wind and surge/flow patterns of an approaching shorenormal hurricane (left column) and shore-parallel hurricane (right column) at times before (A and $\mathrm{B}$ ) and after ( $\mathrm{C}$ and $\mathrm{D})$ the storm passes. $\mathrm{E}$ and $\mathrm{F}$ illustrate the cumulative storm-induced flow directions and morphologic features that can form on undeveloped shorelines in various shoreline impact regimes, their respective locations are indicated by the black boxes. These features do not necessarily need to form on a barrier island or specifically on the ocean side. 


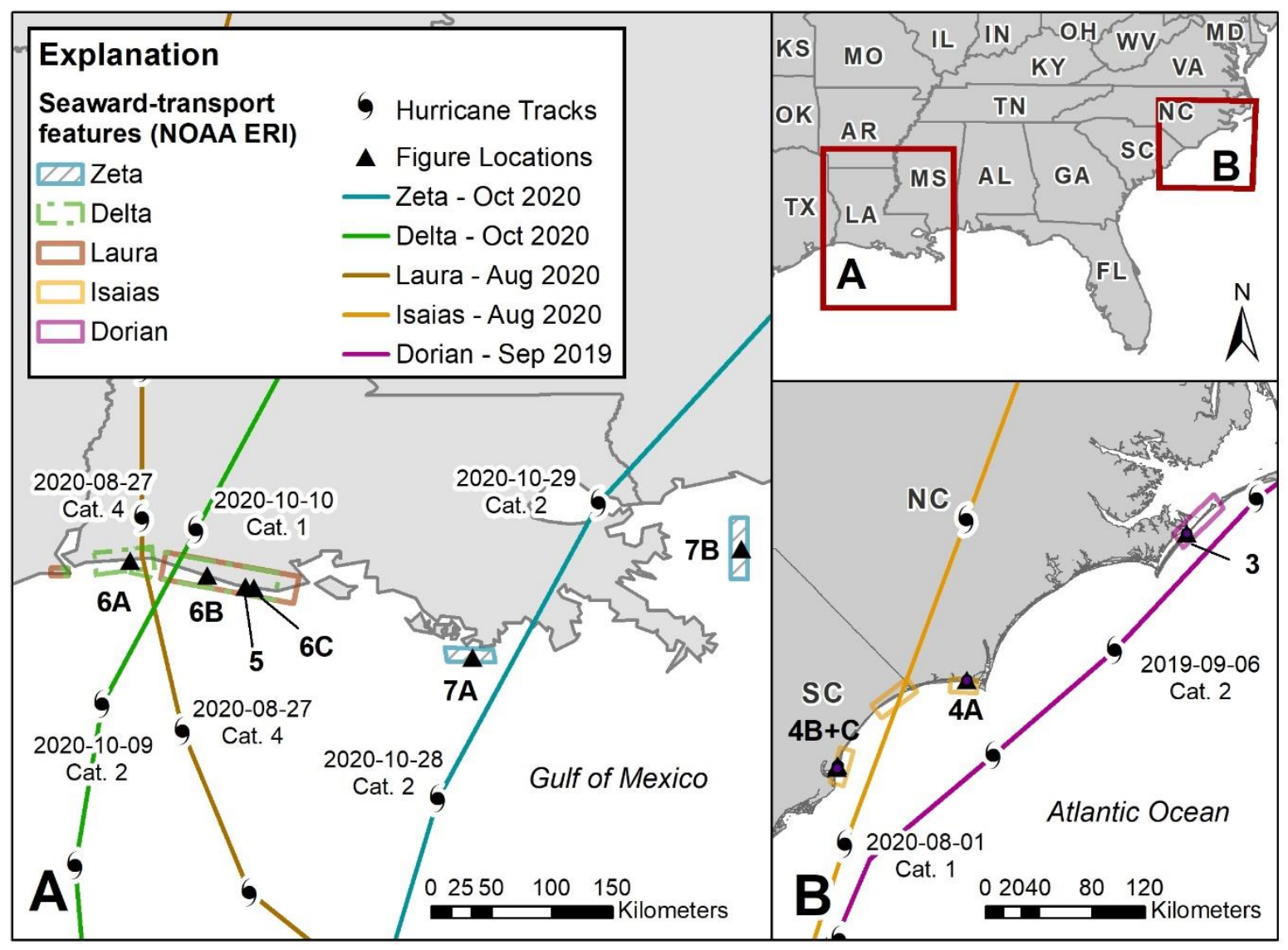

Figure 2. Map showing tracks of hurricanes in the 2019-2020 season that generated seaward return- and seaward-flow features observed in the NOAA ERI, in (A) the Gulf of Mexico and (B) the Carolinas. 

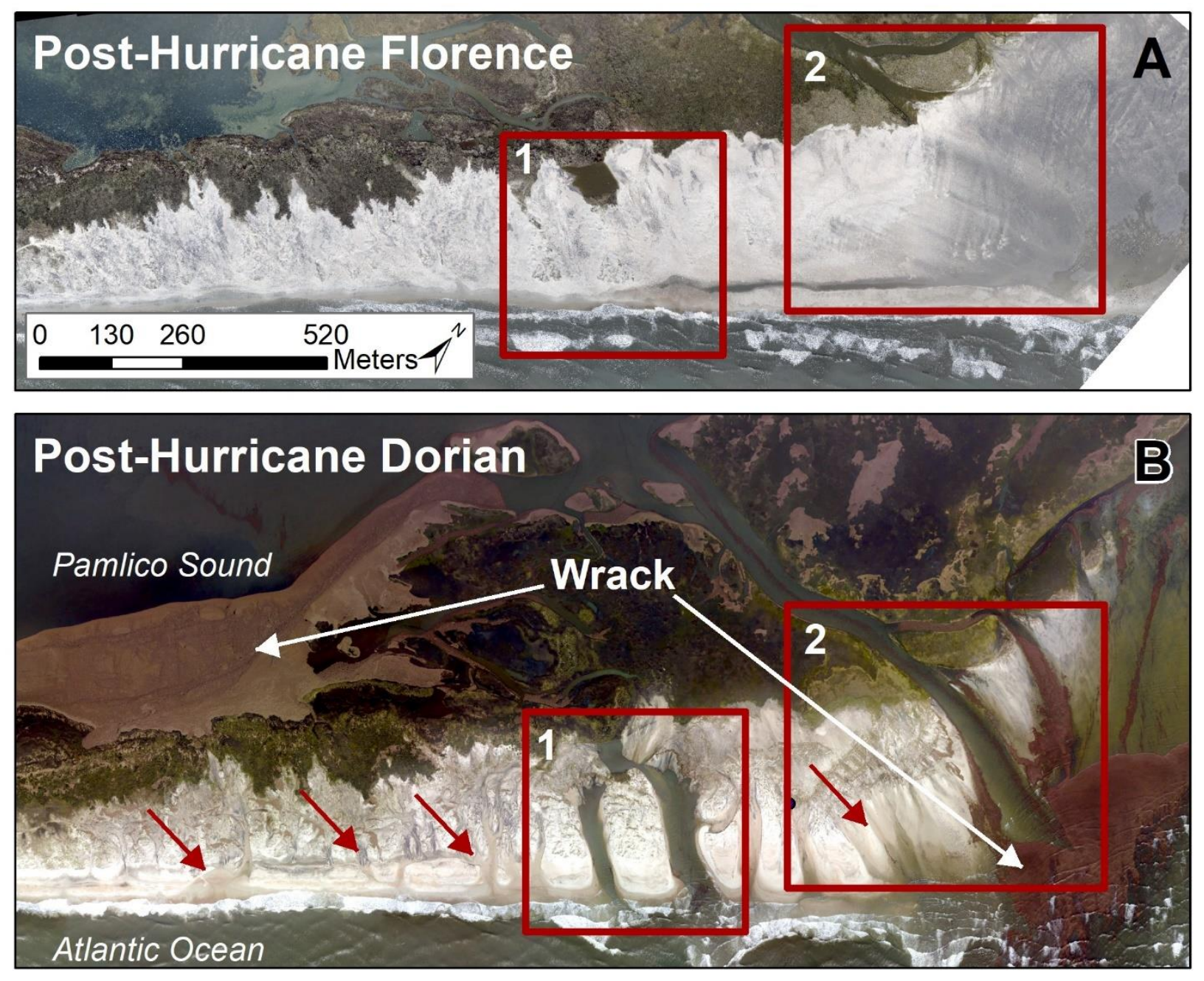

Figure 3. Images of North Core Banks, North Carolina of: (A) post-Hurricane Florence (2018) new and reactivated washout fans and sheetwash, and (B) post-Hurricane Dorian (2019) washout features. The red boxes depict the same areas between images, highlighting post-Dorian observations of the formation of washout channels (Box 1) and an area breaching the entire barrier island, where direction of flow is indicated by the removal of wrack from the back of the island to the ocean side (Box 2). Smaller washout scour features (red arrows) are visible on the beach. See Figure 2 for location information. All imagery is from NOAA ERI (NGS 2018; NGS 2019a). 

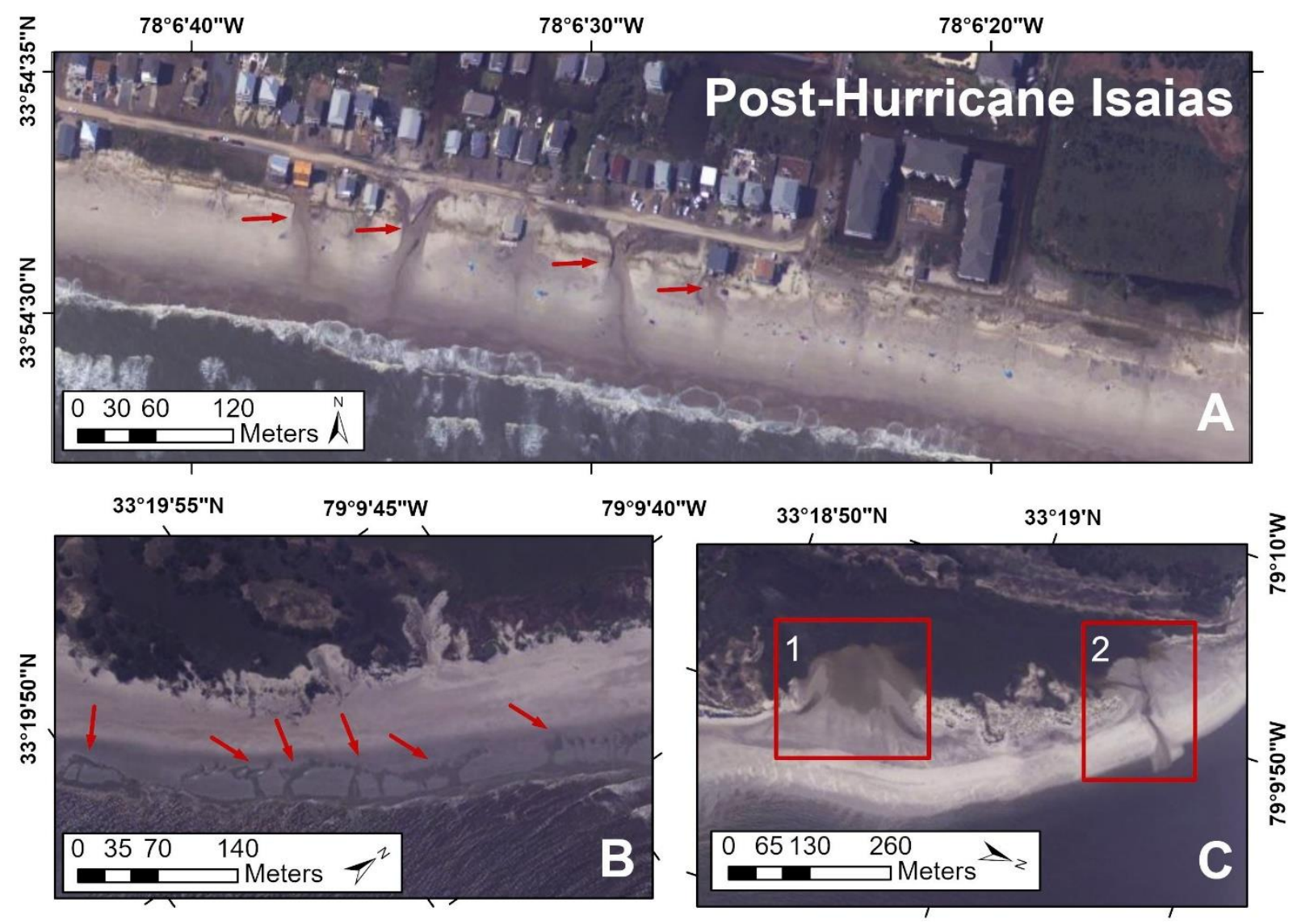

Figure 4. Images after Hurricane Isaias depicting: (A) seaward return scours (red arrows) in a developed area of NC, (B) seaward return scours (red arrows) in SC, and (C) a washover fan (Box 1) and seaward return delta (Box 2) in SC. See Figure 2 for location information. All imagery is from NOAA ERI (NGS 2020d). 

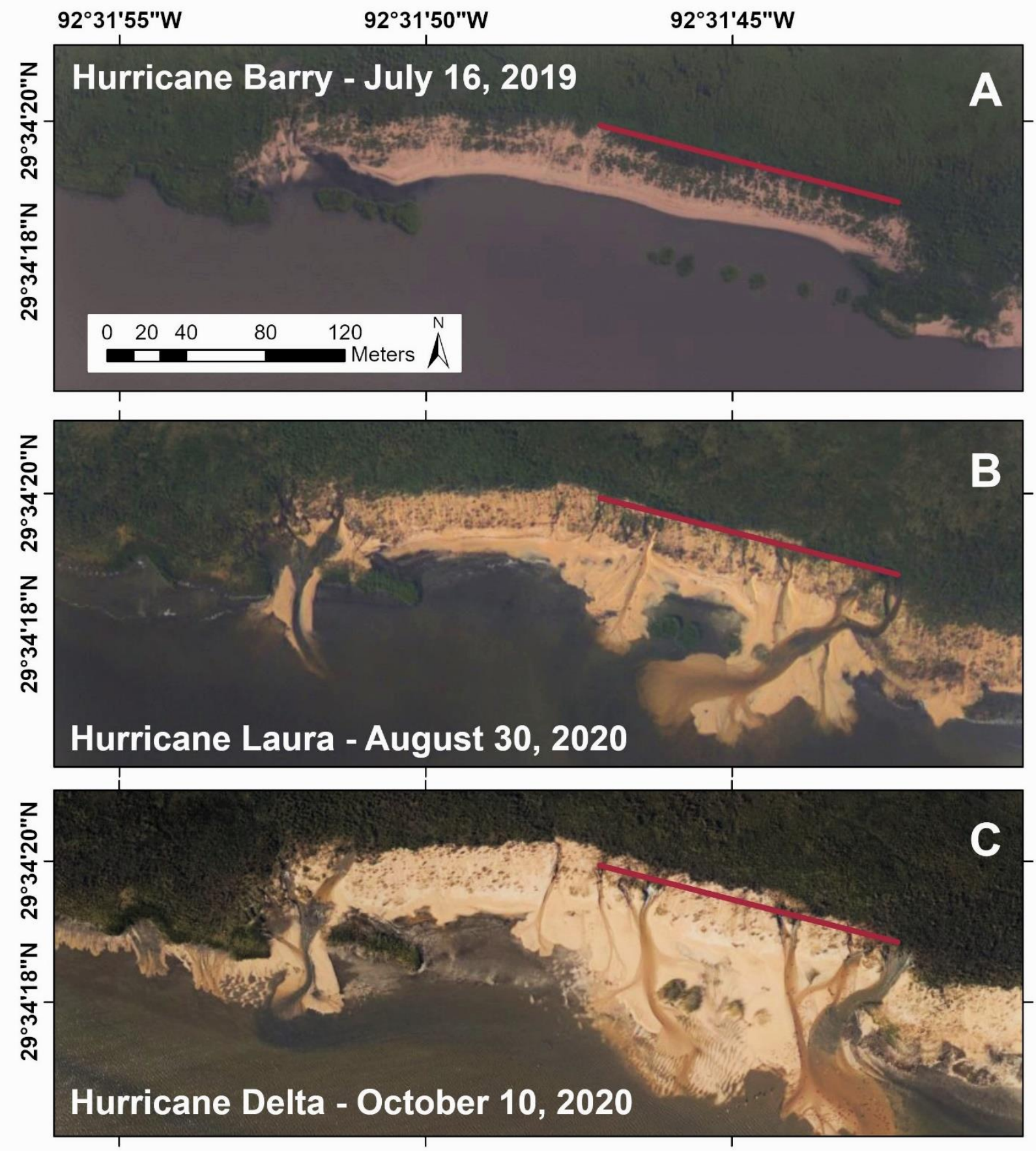

Figure 5. Images of the area east of Flat Lake, Louisiana, showing the formation of multiple return fans and deltas: (A) state of the beach after Hurricane Barry in 2019, (B) after Hurricane Laura, and (C) the same features persist but are slightly reworked after Hurricane Delta. Red bar is for reference. See Figure 2 for location information. All imagery is from NOAA ERI (NGS, 2019b; NGS 2020b; NGS 2020c). 


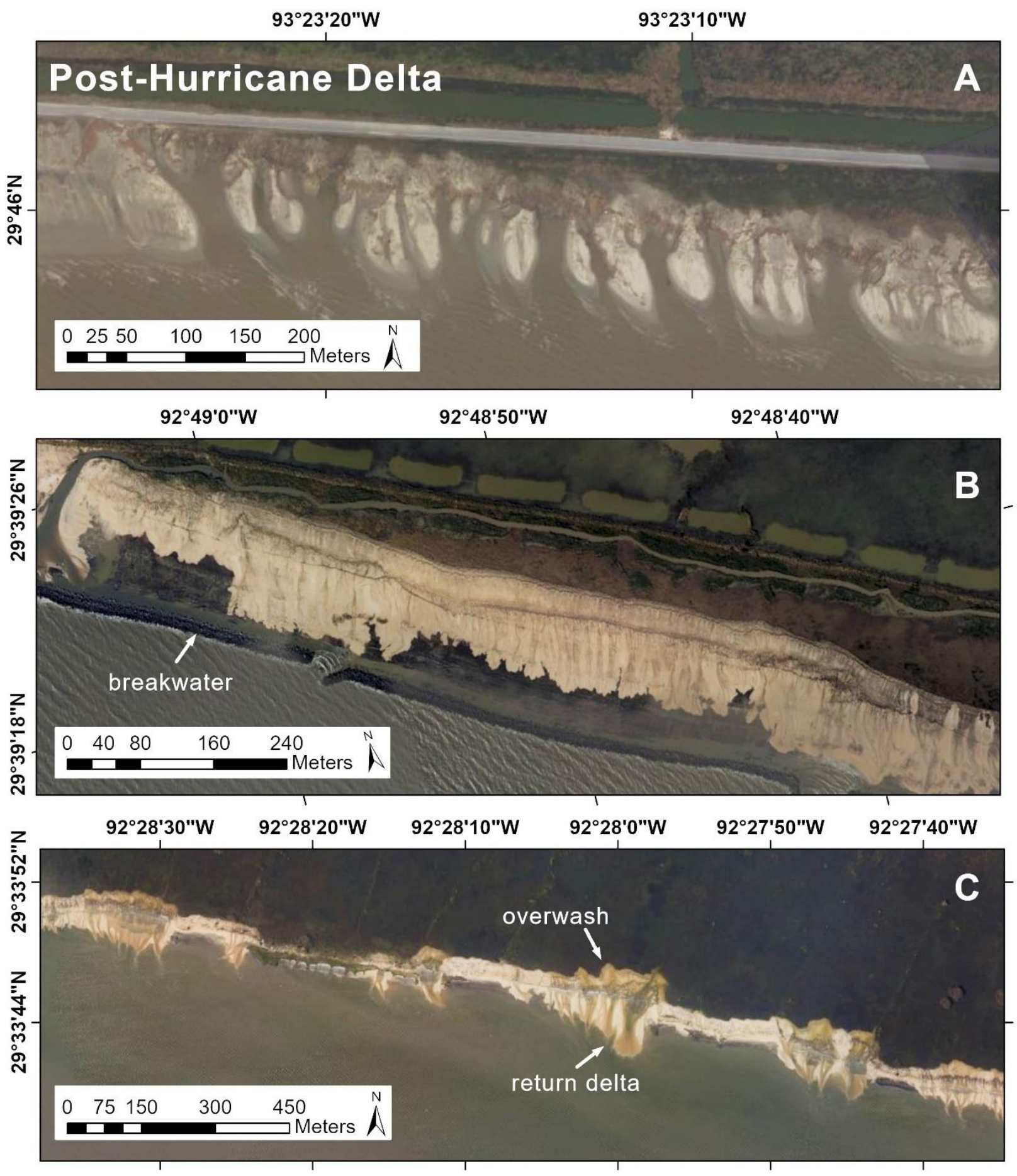

Figure 5. Images of the area east of Flat Lake, Louisiana, showing the formation of multiple return fans and deltas: (A) state of the beach after Hurricane Barry in 2019, (B) after Hurricane Laura, and (C) the same features persist but are slightly reworked after Hurricane Delta. Red bar is for reference. See Figure 2 for location information. All imagery is from NOAA ERI (NGS, 2019b; NGS 2020b; NGS 2020c). 

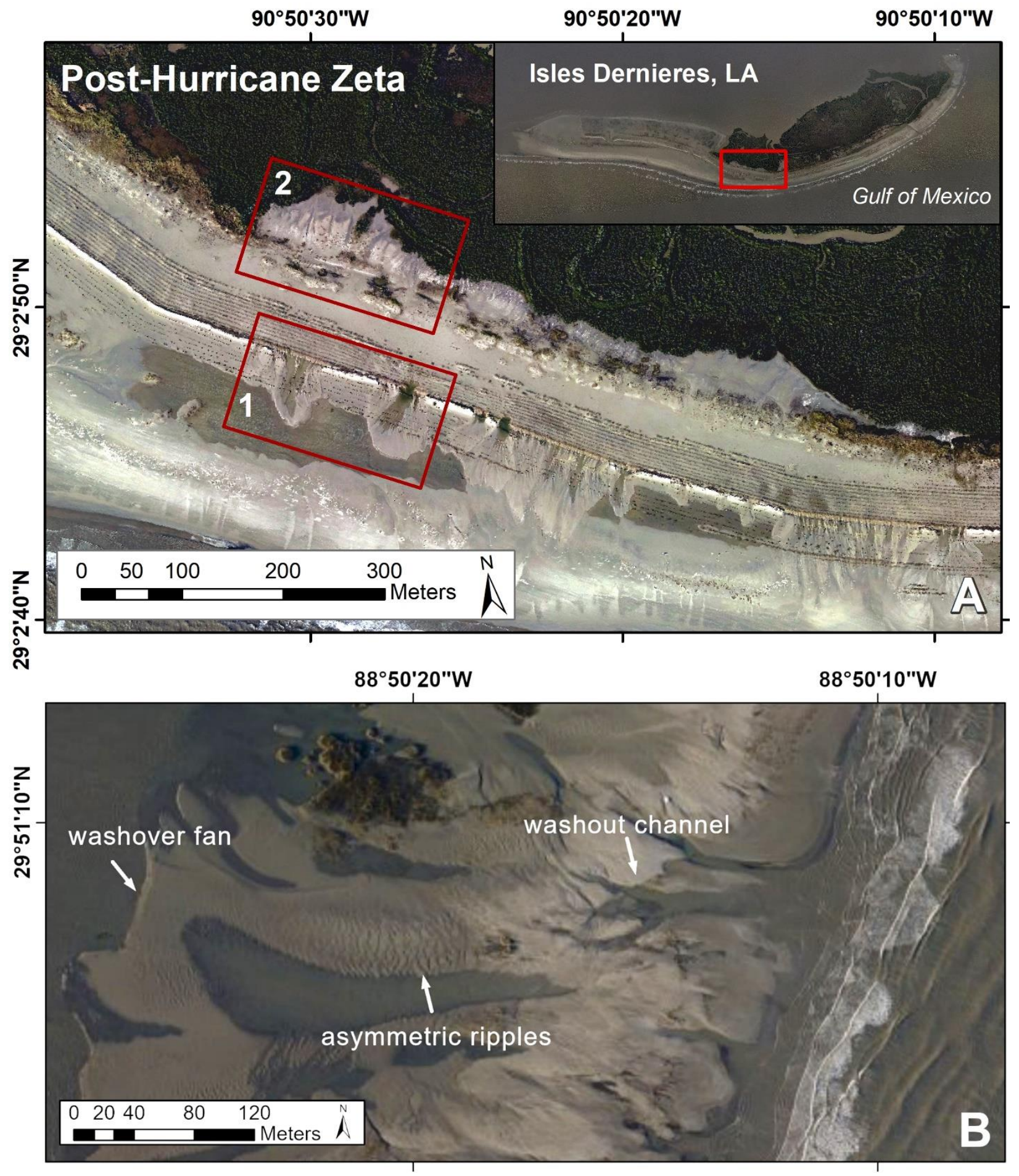

Figure 7. Images of after the passage of Hurricane Zeta (2020) of: (A) a seaward-flow washout fan (Box 1) on the Isles Dernieres Barrier Island Refuge, Louisiana (note that the washover fans in Box 2 were present before Zeta); (B) washover fans covered by seaward-oriented asymmetric bedforms and washout channels on the Chandeleur Islands. See Figure 2 for location information. All imagery is from NOAA ERI (NGS 2020a). 


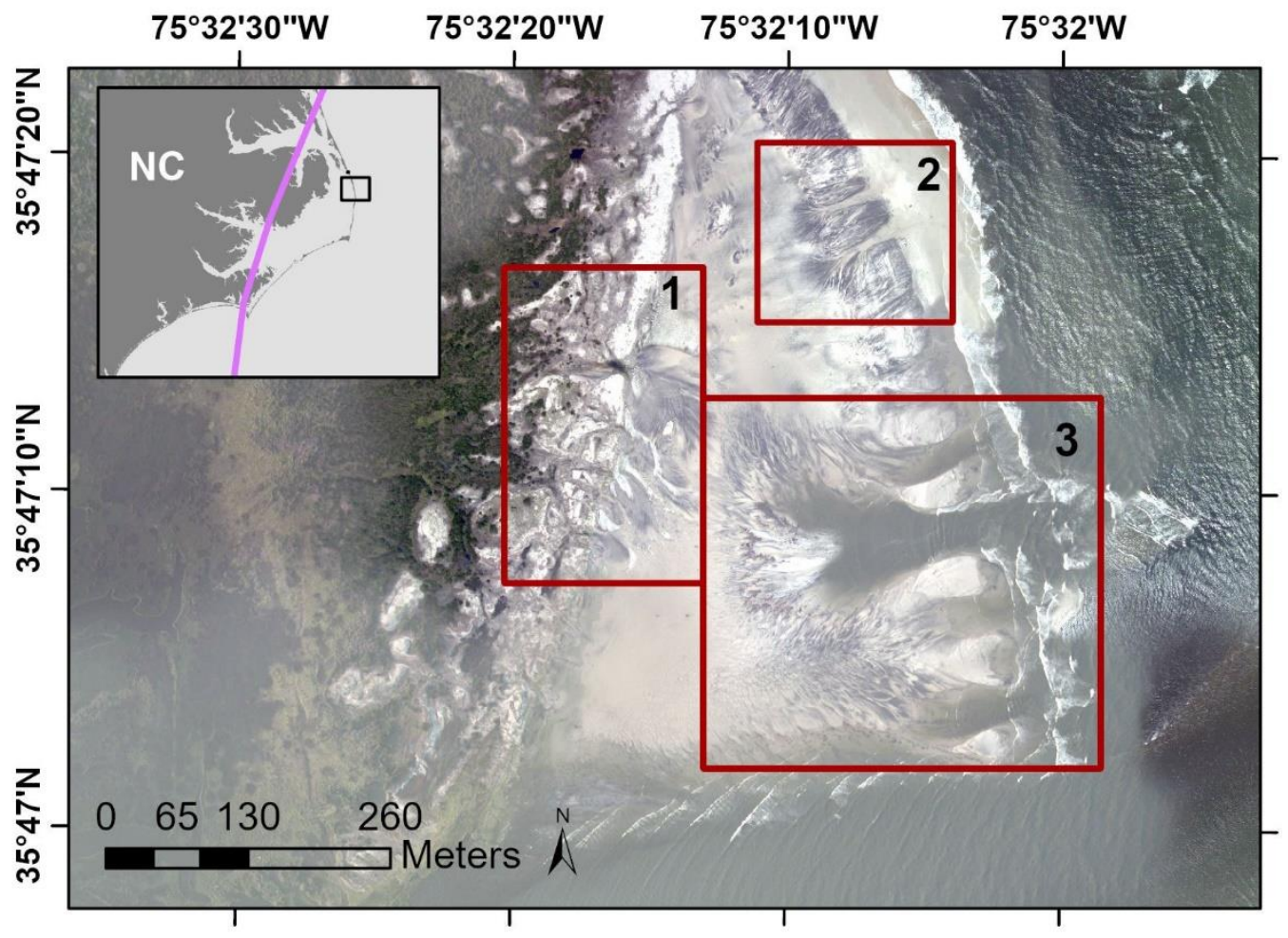

Figure 8. Image just north of Oregon Inlet, North Carolina, after Hurricane Irene (path in pink) in 2011 showing storm-induced features: (Box 1) washout fans splay onto the beach after breaching the dunes; (Box 2) small washout scours appear to have deposited sand on the beach, while (Box 3) the larger washout channels may have transported sediment further offshore. 